\title{
Effects of Dietary Coconut Oil Meal with or without an Enzyme Mixture on Laying Performance and physical parameters of eggs of Japanese Quail (Coturnix coturnix)
}

\author{
T.S Abeysekara and N.S.B.M Atapattu ${ }^{1 *}$ \\ Government Veterinary Surgeon Office \\ Maliban Mawatha \\ Walahanduwa, Galle \\ Sri Lanka
}

\begin{abstract}
The objective of this study was to determine the effects of incorporation of dietary coconut oil meal (COM) upto $20 \%$ with or without an enzyme mixture on egg production of Japanese quail (Coturnix coturnix). A total of 144 quails housed in 36 cages in a completely randomized design with $3 \times 2$ factorial arrangement with six replicates. Each treatment group received one of the six experimental diets ad libitum from 7 to 13 weeks. Experimental factors were three dietary COM inclusion levels (0, 10 and 20\%) and two enzyme levels ( 0 and $0.1 / \mathrm{kg}$ ). The level of COM or supplementary enzyme had no significant effect on bird's live weight. Feed intake and the total egg production of the quails fed with $10 \%$ COM incorporated diet are significantly higher than those of quails fed diets without COM. The level of dietary COM had no effect on weight or the shape index of eggs. Compared to $0 \%, 10 \%$ dietary COM significantly increased the percentage weight of yolk with concomitant reduction in albumin weight. Shell thickness was also significantly improved when quail were fed with 10\% dietary COM. It was concluded that COM could be included upto $20 \%$ in laying Japanese quail diets without adverse effects on production performance. Enzyme supplementation did not improve the performance.
\end{abstract}

Keywords: Coconut oil meal, enzyme, Japanese quail, performance.

\section{INTRODUCTION}

Feed cost accounts for more than $70 \%$ of the total recurrent cost of production and thus greatly influences the profitability of quail production and the affordability of meat or eggs to consumers. Inclusion of cheap, locally available agricultural by-products such as coconut oil meal or copra in diets at higher levels, replacing ingredients such as soybean meal and maize meal could reduce the feed cost while minimizing adverse environmental impacts associated with livestock, including quail. Nutritive value of coconut oil meal has been reported to be poor due to low concentrations of several limiting amino acids, high levels of dietary fiber and non starchy polysaccharides, and the rancidity (Sundu et al., 2006). Hence, COM is included at low levels in practical poultry diets. Panigrahi et al. (1989) found no adverse effects of $20 \% \mathrm{COM}$ on laying performance of chicken whereas Moorthy and

\footnotetext{
1 Department of Animal Science, Faculty of Agriculture, University of Ruhuna, Mapalana, Kamburupitiya, Sri Lanka

* Corresponding author: nsbm@ansci.ruh.ac.lk
} 
Wishwanathan (2006) recommended not more than 10\% dietary COM for better egg production. Meanwhile, Sundu et al. (2004) reported that inclusion of COM had negative effects on 1-14 days old broiler chicks. Attempts have been made to address the anti nutritional problems of COM by either carefully formulating diets to meet nutrient requirements, particularly amino acids or by the inclusion of enzymes (Pluske et al., 1997). Objective of this study was to determine the effects of incorporation of COM upto $20 \%$ with or without an enzyme mixture (BIO-GRAIN CG) on egg production of Japanese Quails.

\section{METHODOLOGY}

Four-weeks old female Japanese quails $(\mathrm{n}=144)$ were allocated into 36 stacked cages. During the three weeks of the acclimatization period, birds were fed commercial layer starter crumbles (Prima Feeds, Sri Lanka) containing $2700 \mathrm{ME} \mathrm{Kcal/Kg}$ and $18 \%$ crude protein. At the end of the sixth week of age, birds were weighed and cages were randomly allocated for 6 dietary treatments. The between cage live weight variation was minimized. The experiment was conducted in a completely randomized design with $3 \times 2$ factorial arrangement. Treatment factors were three dietary COM levels $(0,10$ or $20 \%)$ and two enzyme levels (BIO-GRAIN CG, Advanced Bio-Agro Tech Limited, India; 0 or $0.1 \mathrm{~g} / \mathrm{Kg}$ ). The enzyme mixture contained Cellulase, Xylanase, Pectinase, Amylase, Lipase, Protease, Glucanase and other NSP degrading enzymes (http://www.indiamart.com/advancedbioagrotech/animalfeed-supplement.html). Each treatment combination had six replicate cages with four birds. Each composition of the diets and the nutrient levels are given in Table 1.

Birds were given experimental diets and water ad libitum for seven weeks from the $7^{\text {th }}$ to $13^{\text {th }}$ week. Two eggs randomly collected from each cage were used to determine weight components of egg and cholesterol content of egg yolk seven weeks after the dietary treatment. Weight, length and width of each egg were measured after break opening for measuring parameters of inner content. The yolk fresh weight was recorded by gently separating the yolk from the albumin where adherent albumin was removed by rolling the yolk over a tissue paper. Shells were air dried for three days and then oven dried at $65^{\circ} \mathrm{C}$ for three days to get shell weight. Shell thickness was measured using an egg shell thickness meter (Orawa, Seiki, Japan). The fresh weight of the albumin was calculated by substracting the shell and yolk weights from the total egg weight.

Shape index of the each egg was calculated as follows;

Shape index $=$ maximum width/maximum length $\mathrm{x} 100$

Data were analyzed using SAS (1989). Significant main effects were compared using the Duncan Multiple Range Test (DMRT) while significant interactions were compared using the LS mean comparison procedure. 
Table 1. Composition of experimental diets and their nutritional levels

\begin{tabular}{|c|c|c|c|}
\hline \multirow{2}{*}{ Ingredient } & \multicolumn{3}{|c|}{ Dietary COM level (\%) } \\
\hline & $\mathbf{0}$ & 10 & 20 \\
\hline Coconut oil meal & 0 & 10 & 20 \\
\hline Yellow maize meal & 58 & 52.85 & 43 \\
\hline Coconut oil & 0.9 & 0.9 & 3.85 \\
\hline Soya bean meal & 33.15 & 27.14 & 24.15 \\
\hline Fish meal & 0.5 & 1.7 & 2.05 \\
\hline Trace Mineral/Vit.mix & 0.25 & 0.25 & 0.25 \\
\hline Dicalcium Phosphate & 1.1 & 1 & 0.9 \\
\hline Shell powder & 5.7 & 5.5 & 5.45 \\
\hline DL Methionine & 0.15 & 0.15 & 0.1 \\
\hline Salt & 0.25 & 0.25 & 0.25 \\
\hline Enzymes & $-/+$ & $-/+$ & $-/+$ \\
\hline \multicolumn{4}{|c|}{ Calculated nutrient composition } \\
\hline Crude protein $(\%)$ & \multicolumn{3}{|c|}{20} \\
\hline Energy (ME Kcal/kg) & \multicolumn{3}{|c|}{2700} \\
\hline Lysine (5) & \multicolumn{3}{|c|}{1} \\
\hline Methionine + Cysteine & \multicolumn{3}{|c|}{0.74} \\
\hline Non phytate phosphorus & \multicolumn{3}{|c|}{0.35} \\
\hline Calcium $(\%)$ & \multicolumn{3}{|c|}{2.5} \\
\hline
\end{tabular}

\section{RESULTS AND DISCUSSION}

No mortality occurred during the experimental period. The level of COM or supplementary enzyme had no significant effect on birds live weight (Table 2). Feed intake and the total egg production of the quail fed with $10 \%$ COM incorporated diet was significantly higher than those of quails fed diet incorporated with $0 \%$ and $20 \%$ COM. Wignjosoesastro et al. (1972) have also reported a linear increase in feed intake when COM was added to layer diets. Furthermore, positive effects of $10 \% \mathrm{COM}$ on the laying (Wignjosoesastro et al., 1972) and growth performance of Japanese quail (Creswell and Brooks, 1971) have been reported. The COM contains a large amount of mannan oligosaccharides (MOS) consist with repeating $\beta$ 1,4 mannose units and a few $\alpha-1,6$ galactose units attached to the $\beta-1,4$ mannose backbone (Hossain et al., 1996). Beneficial effects of MOS in poultry have been well documented (Berry and Lui, 2000; Çabuk et al., 2006; Gürbüz et al., 2011; Gibson et al., 2000). Findings of the present study support the hypothesis by Sundu et al. (2012) that COM could be used as a source of mannan oligosaccharides to promote the production performance of poultry. 
Table 2. Effects of dietary COM levels and enzyme supplementation on laying performance and physical parameters of egg and egg shell of Japanese Quail

\begin{tabular}{|c|c|c|c|c|c|c|c|c|c|c|}
\hline \multirow[t]{4}{*}{ Parameter } & \multicolumn{6}{|c|}{ Dietary COM level (\%) } & \multirow{4}{*}{$\begin{array}{l}\text { Pooled } \\
\text { SEM }\end{array}$} & \multicolumn{3}{|c|}{ Level of significance $^{T}$} \\
\hline & \multicolumn{2}{|c|}{0} & \multicolumn{2}{|c|}{$\begin{array}{c}10 \\
\text { Enzyme }\end{array}$} & \multicolumn{2}{|c|}{20} & & \multirow{3}{*}{ Level } & \multirow{3}{*}{ Enzyme } & \multirow{3}{*}{ COM*Enzyme } \\
\hline & 0 & + & 0 & + & 0 & + & & & & \\
\hline & \multicolumn{6}{|c|}{ Egg production } & & & & \\
\hline $\begin{array}{l}\text { Live weight (g) } \\
\text { on week } 7\end{array}$ & 190 & 183 & 181 & 179 & 174 & 182 & 4.2 & NS & NS & NS \\
\hline week 13 & 178 & 179 & 180 & 184 & 178 & 188 & 8.1 & NS & NS & NS \\
\hline $\begin{array}{l}\text { Egg production } \\
\text { on } 7^{\text {th }} \text { week }\end{array}$ & 4.1 & 3.2 & 3.8 & 4.3 & 4.6 & 4.8 & 0.58 & NS & NS & NS \\
\hline & 3.6 & 3.5 & 5.5 & 5.3 & 4.8 & 3.8 & 0.6 & $*$ & NS & NS \\
\hline & 30 & 2.6 & 41 & 48 & 38 & 2.8 & 0.5 & $* *$ & NS & NS \\
\hline $11^{\text {th }}$ week & & & & & & & & & & \\
\hline $13^{\text {th }}$ week & 2.3 & 2.8 & 2.8 & 3.8 & 2.3 & 2.0 & 0.5 & 0.08 & NS & NS \\
\hline $\begin{array}{l}\text { Total egg } \\
\text { production }\end{array}$ & 24.0 & 22.8 & 30.1 & 31.6 & 28.8 & 25.0 & 2.4 & $*$ & NS & NS \\
\hline $\begin{array}{l}\text { Feed intake } \\
(\mathrm{g} / \mathrm{b} / \mathrm{d})\end{array}$ & 22.5 & 25.6 & 25.8 & 26.3 & 23.2 & 25.9 & 0.7 & $* *$ & $* *$ & NS \\
\hline Egg parameters & & & & & & & & & & \\
\hline Egg weight (g) & 9.0 & 9.8 & 9.1 & 9.6 & 10.0 & 9.6 & 0.2 & NS & NS & NS \\
\hline Yolk \%) & 34.3 & 32.8 & 37.6 & 39.6 & 37.1 & 37.5 & 1.9 & $*$ & NS & NS \\
\hline Albumin $(\%)$ & 55.0 & 56.8 & 51.3 & 49.5 & 52.0 & 51.0 & 2.1 & $*$ & NS & NS \\
\hline Shell (\%) & 10.4 & 10.3 & 10.6 & 10.5 & 11.0 & 11.5 & 0.3 & NS & NS & NS \\
\hline $\begin{array}{l}\text { Shell thickness } \\
(\mathrm{mm})\end{array}$ & 0.24 & 0.25 & 0.28 & 0.27 & 0.26 & 0.29 & 0.007 & $* *$ & NS & $*$ \\
\hline Shape index & 80.6 & 79.6 & 79.2 & 78.9 & 79.9 & 78.9 & 1.4 & NS & NS & NS \\
\hline
\end{tabular}

NS, $\mathrm{p}>0.05 ;{ }^{*} \mathrm{p}<0.05 ; * * \mathrm{p}<0.01$

The positive effect of $10 \%$ COM on egg production was high during $9^{\text {th }}(\mathrm{P}<0.05), 11^{\text {th }}$ weeks $(p<0.01)$ but reduced by $13^{\text {th }}$ week. But this reduction was not significant $(p>0.05)$. Wignjosoesastro et al. (1972) have also reported that positive effects of COM on egg production declined after fourth week of feeding. Similarly, Shashidaran and Devgawda (2003) found MOS had positive effects on egg production of layer chicken for only three weeks. Beneficial effects of MOS are reported to be due to the improved immune response. Since birds develop immunity with age, older birds may not be benefitted from supplemental MOS. Sundu et al. (2012) have reported that non starchy polysaccharides in soybean meal and COM tend to reduce the feed intake. Enzyme mixture seems to have mitigated those adverse effects and significantly have improved the feed intake in the present study.

Apart from feed intake, none of the production performance parameters was significantly influenced by the supplementary enzyme mixture. The non significant effect of enzyme supplementation observed in the current study is probably due, in large part, to the fact that the inclusion of COM had no negative effect on egg production parameters. Thus, there were no negative effects to be mitigated by enzyme inclusion. 
The level of dietary COM had no effect on egg weight or the shape index but on the relative weights of egg components. In contrast, Wignjosoesastro et al. (1972) reported a reduction in egg weight at $10 \%$ incorporation level of COM in the diet. Compared to $0 \%, 10 \%$ dietary COM significantly increased the percentage weight of yolk with concomitant reduction in albumin weight (Table 2). Bozkurt et al. (2012) observed a significant increase in relative egg yolk weight without any effect on albumin of the laying hen fed mannan oligosaccharide supplemented diets. There was a significant $(p<0.05)$ COM level $x$ enzyme interaction for shell thickness. Enzyme supplementation increased the shell thickness while the same had negative effect at 20\% COM level. The shell thickness was also significantly improved when quail were fed with $10 \%$ COM.

\section{CONCLUSIONS}

It was concluded that COM could be included upto $20 \%$ in laying Japanese quail diets without adverse effects on production performance. Inclusion of $10 \% \mathrm{COM}$ found to have beneficial effects on laying performance. However the growth was not improved by the inclusion of COM. Enzyme supplementation did not improve the performance.

\section{REFERENCES}

Berry, W.D. and Lui, P. (2000). Egg production, egg shell quality and bone parameters in broiler breeder hens receiving Biol.-Mos and Eggshell 49. Poult. Sci. 79 (1), 124. (Abstr.)

Bozkurt, M., Küçükyilmaz, K., Catli, A.U., Çınar, M., Bintaş, E. and Çöven, F. (2012). Performance, egg quality, and immune response of laying hens fed diets supplemented with mannan-oligosaccharide or an essential oil mixture under moderate and hot environmental conditions. Poultry science. 91(6), 1379 - 1386.

Çabuk, M., M. Bozkurt, A. Alçiçek, A.U. Çatlı, and K.H.C. Başer. (2006). The effect of a mixture of herbal essential oils, a mannan oligosaccharide or an antibiotic on performance of laying hens under hot climatic conditions. S. Afr. J. Anim. Sci. 36, 135 - 141.

Creswell, D.C. and Brooks, C.C. (1971). Effect of coconut meal on coturnix quail and of coconut meal and coconut oil on performance, carcass measurements and fat composition in swine. Journal of animal science. 33(2), 370 - 375.

Gibson, G.R., Ottaway, P.B. and Rastall, R.A. (2000). Prebiotics: new developments in functional foods. Chandos Publishing, Oxford, UK.

Gürbüz, E., Balevi, T., Kurtoğlu, V. and Öznurlu, Y. (2011). Use of yeast cell walls and Yucca schidigera exctract in layer hens' diets. Ital. J. Anim. Sci. 10, 134-138.

Hossain, M.Z., Abe, J. and Hizukuri, S. (1996). Multiple forms of mannanase from Bacillus sp. KK01. Enzyme Microb Technol. 18, 95 - 98.

Moorthy, M. and Viswanathan, K. (2006). Feeding value of extracted coconut meal for white Leghorn layers. Int. J. Poult. Sci. 5(11), 1040 - 1045. 
Panigrahi, S. (1989). Effects on egg production of including high residual lipid copra meal in laying hen diets. Brit. Poult Sci. 30(2), 305 - 312.

Pluske, J.R., Moughan, P.J., Thomas, D.V., Kumar, A. and Dingle, J.G. (1997). Releasing energy from rice bran, copra meal and canola in diets using exogenous enzymes. pp. 81-94. In: 13th Annual Alltech Symposium. Notingham University Press. Notingham, UK.

Shashidharan, R.G. and Devegowda, G. (2003). Effect of dietary mannan oligosaccharide on broiler breeder production traits and immunity. Poult. Sci. 82(8), 1319 - 1325.

Sundu, B., Hatta, U., and Chaudhry, A.S. (2012). Potential use of beta-mannan from copra meal as a feed additive for broilers. World's Poul. Sci. J. 68(04), 707 - 716.

Sundu, B., Kumar, A. and Dingle, J. (2004). The effect of levels of copra meal and enzymes on bird performance. pp. 52-54. In Proceedings of the 16th Australian Poultry Science Symposium. Sydney, New South Wales, Australia. 9-11 February 2004. Poultry Research Foundation.

Sundu, B., Kumar, A. and Dingle, J. (2006). Response of broiler chicks fed increasing levels of copra meal and enzymes. Int. J. Poult. Sci. 5(1), 13 - 18.

Wignjosoesastro, N., Brooks, C.C. and Herrick, R. B. (1972). The effect of coconut meal and coconut oil in poultry rations on the performance of laying hens. Poult. Sci. 51(4), 1126 1132 . 